\title{
Design of Electronic Mass Balance of Gram Scale Using a Gage Strain Sensor
}

\author{
Muhammad Priyono Tri Sulistyanto ${ }^{1}$, Kurriawan Budi Pranata ${ }^{2}$, Endarko ${ }^{3}$, Melania Suweni Muntini ${ }^{4}$
}

\begin{abstract}
This research is conducted by utilizing strain gage uniaxial sensor with internal resistance $120 \mathrm{ohms}$ and brass cantilever beam that is to build electronic mass scale in gram level. Basically, the aim of this research is to study deflect phenomenon measured by the strain gage sensor attached in the end of brass cantilever beam. Brass material was chosen to build cantilever as its Young moudulus contanst is bigger than other materials. Whilst mass loads for analizing brass cantilever profile are calibrated by manual Ohaus mass scale (PA214 type) with 0.07 gram load variations. The test result of this electronic mass scale system gets relationship of mass load data variation versus output voltage data (from differential amplifier). The relationship between mass and voltage can be approached by polynomial formula $\mathrm{m}=4.2372 \mathrm{~V}^{2}-2.4551 \mathrm{~V}+1.5606$ where $\mathrm{m}$ in gram and $V$ in volt, and it gets 0.07 or $7 \%$ average error (less than linear formula approach). This formula is used further for programming ADC in 8-bit microcontroller to calculate mass and the calculation is shown in LCD 16x2.
\end{abstract}

Keywords - electronic mass scale, strain gage, brass cantilever

\section{INTRODUCTION}

Measurement is the process of determining one or more values that can be related to a magnitude or in other sense means a process comparing with a quantity [1], [2]. Measurement of mass of an object can be done by using swing balance, spring balance, or electronic balance. Prior research on the use of strain gage as a massive data logger on a scale of hundreds of grams has been done [3]. In a previous study, it was used four strain gage sensors installed in the load cell system. In this paper, this research was carried out in the development of electronic balance sheets on a smaller scale, namely the gram order with a precision of 0.07 grams, which utilized strain symptoms in the material resulted from the addition of mass and cantilevered rods [4]. Material properties could be demonstrated through strain relationships and stress as shown in Fig. 1.

Fig. 1 shows the elastic condition of the material in a linear region (elastic region). It appears that strain changes are directly proportional to stress directed at the material. The elastic condition of the material will stop when the material can not maintain its shape with increasing strain (plastic area),

${ }^{1}$ Lecturer, Program Studi Teknik Informatika, Universitas Kanjuruhan Malang, Jln S. Supriyadi No.48 Malang 65148,INDONESIA (e-mail: m.priyono.ts@unikama.ac.id)

${ }^{2}$ Lecturer, Program Studi Pendidikan Fisika, Universitas Kanjuruhan Malang, Jln S. Supriyadi No.48 Malang 65148,INDONESIA (e-mail: kurriawan@unikama.ac.id)

${ }^{3,4}$ Lecturer, Program Studi Ilmu Fisika, Fakultas Matematika dan Ilmu Pengetahuan Alam, Institut Teknologi Sepuluh Nopember, Jln. Arief Rahman Hakim, Surabaya 60111, INDONESIA. so that if loading is reduced, the material can not return to its original position and shape.

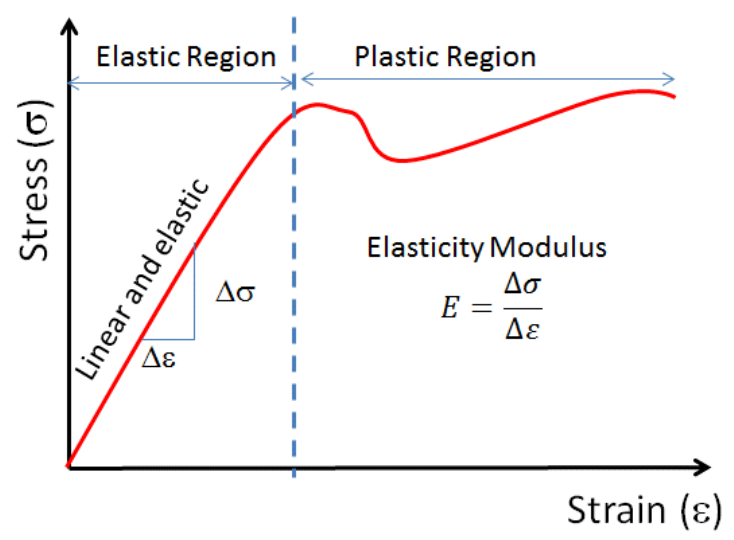

Fig. 1 The relationship between stress versus strain of the material.

The concept of this measurement utilizes the elasticity of the material due to the change in size/deflection due to the increase of force perpendicular to the surface plane at the material end, as shown in Fig. 2. The greater the load/force $(F)$ will reach the maximum deflection value $\left(\delta_{\max }\right)$ as the proportional limit of a material shown in Fig. 1.

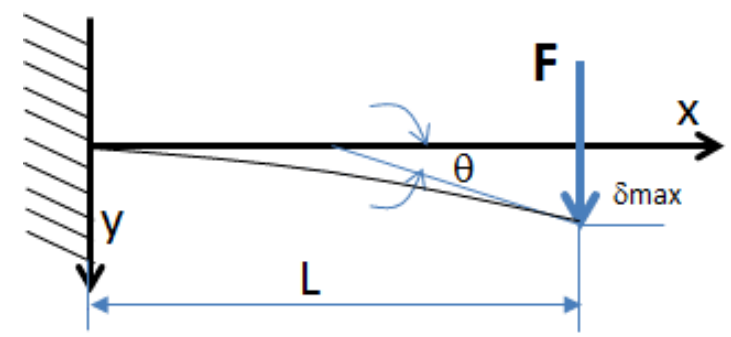

Fig. 2 Deflection of an elastic material when given a load/force.

The relationship between the compressive force (F) is very close to the physical quantity of stress $(\sigma)$, since stress arises from the force acting on the cantilever rod. Hence, it can be formulated in (1).

$$
\sigma=\frac{F}{A}
$$

with $\sigma$ is the amount of stress $(\mathrm{N} / \mathrm{m} 2), \mathrm{F}$ is the compression force $(\mathrm{N})$ worked on the surface of the material end, and $\mathrm{A}$ represents the cross-sectional area of the material $(\mathrm{m} 2)$. Based on (1) and the coordinate relationship in Fig. 1, it is clear that stress has a very close relationship with the strain as clarified in (2).

$$
\varepsilon=\frac{\sigma}{E}
$$


Equation (2) shows that the strain $\varepsilon$ has a close physical relationship with the compression force $\mathrm{F}$ (in units of $\mathrm{N}$ ), and the relationship is inversely proportional to the elasticity modulus of the material $\mathrm{E}$ (in units of $\mathrm{N} / \mathrm{m} 2$ ). From this description, a concept of mass balance system design that utilizes the modulus of elasticity of a material due to changes in deflection due to the addition of an external force load perpendicular to the surface of the cantilevered rod is obtained. The force from the outside can be gravity, so that the mass variable can be determined.

The change of the strain imposed on the material has a very small change value, therefore it needs a measurement on a micro scale. To measure changes in micro-strains electronically, strain gage sensors can be used [5]. This gage strain has the value of resistance changes in a very small scale (microstrain) when deflected. Therefore, a Wheatstone circuit integrated with an operational amplifier is required to obtain a voltage value [6]. Furthermore, the data is processed inside an 8-bit microcontroller and the mass calculation of the calibration formula is displayed on a 16x2 LCD screen [7].

\section{MethodolOgy}

\section{A. Selection of Cantilever Material}

The material in the design of this cantilevered rod system, the brass material, is the one that has Young's modulus value higher than other materials, as shown in Table I. This means that brass is more difficult to deflect in the form of elongation or shortening than other materials.

TABLE I

Mechanical Features of SeVEral Materials [8]

\begin{tabular}{|c|c|c|c|c|}
\hline Properties & Aluminium & Brass & Magnesium & Zinc \\
\hline $\begin{array}{c}\text { Tensile strength } \\
\text { psi x 1000 }\end{array}$ & 47 & 55 & 34 & 41 \\
\hline $\begin{array}{c}\text { Yield strength, } \\
\text { psi x 100 (0.2 pct } \\
\text { offset) }\end{array}$ & 23 & 30 & 23 & - \\
\hline $\begin{array}{c}\text { Shear strength, } \\
\text { psi x 1000 }\end{array}$ & 28 & 37 & 20 & 31 \\
\hline $\begin{array}{c}\text { Fatigue strength, } \\
\text { psi x 1000 }\end{array}$ & 20 & 25 & 14 & 7 \\
\hline $\begin{array}{c}\text { Modulus of elasticity, } \\
\text { psi x 10E6 }\end{array}$ & 10.3 & 15 & 6.5 & - \\
\hline
\end{tabular}

B. Cantilever System Design

Cantilever in the gram scale of mass measurement system is designed not to be easily broken when given mass load. Thus, a cantilevered rod of brass material with long dimension (1), width (w), and thickness ( $t$ ) is small enough, as shown in Fig. 3.

The strain gage sensor used was the strain gage KFG $120 \Omega$ Uniaxial with serial number KFG-5-120-C1-16LL1M2R [9]. Fig. 4 shows the physical form of this strain gage. This strain gage has a resistance of $120 \mathrm{ohm}$ with a constant factor of $\mathrm{K}_{\mathrm{s}}$
$=2$ gage, which is capable of detecting strains up to 50,000 microstrains.

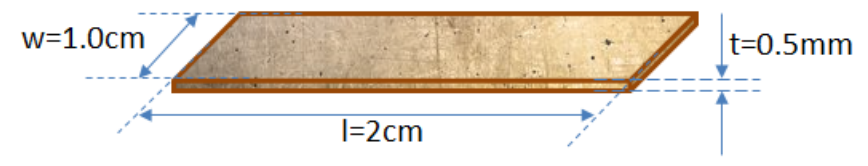

Fig. 3 Illustration of brass cantilevered rods.

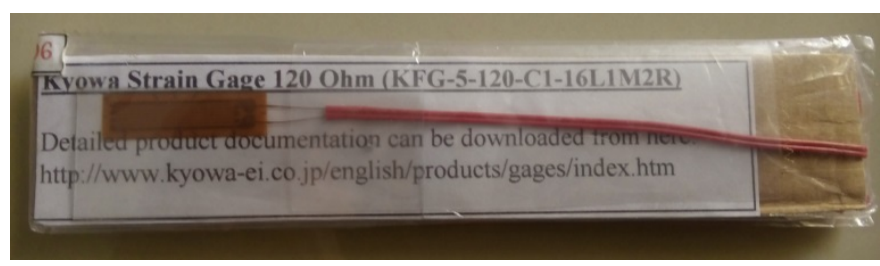

Fig. 4 Physical form of strain gage KFG 120 ohm uniaxial.

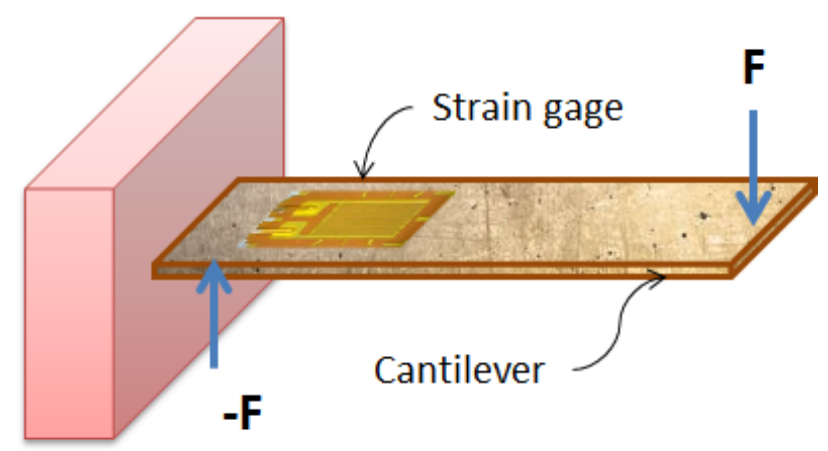

Fig. 5 The location of the sensor on the cantilevered rod.

The measurement system design uses a cantilevered rod from a brass material with one end mounted statically while the other end is charged and the strain gage sensor is attached to the cantilevered rod surface, as shown in Fig. 5. The cantilevered rods will be deflected if any force $\mathrm{F}$ loading is added in a perpendicular direction to the cantilevered rod surface with resistance changes from the strain gage sensor.

\section{Conditioning of the Strain Gage Sensor Signal}

The change in resistance value of this strain gage is very small and needs to be converted to voltage through the Wheatstone bridge circuit, shown in Fig. 6.

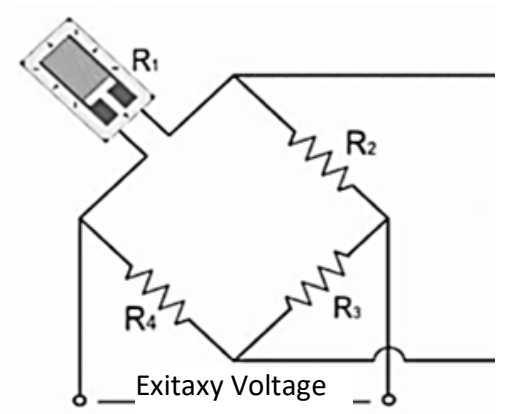

Fig. 6 The series of Wheatstone bridges coupled with strain gage as a variable resistor [3]. 
The excitation voltage, Vin, is 2 volts with the value of R1 $=\mathrm{R} 2=\mathrm{R} 3=\mathrm{R} 4=\mathrm{R}$ and the value of $\mathrm{R} 1$ changes according to the compression force whose resistance value will be $\mathrm{R} 1=\mathrm{R}$ $+\Delta \mathrm{R}$. The output voltage, Vo, is shown in (3) and (4). Furthermore, the Vo voltage is coupled to signal conditioners with gain 1,000 times using Analog IC AD521 [10], [11].

$$
\begin{aligned}
& \boldsymbol{V}_{\text {o }}=\boldsymbol{V}_{\text {in }}\left(\frac{\boldsymbol{R}}{2 \boldsymbol{R}+\Delta \boldsymbol{R}}-\frac{\boldsymbol{R}}{2 \boldsymbol{R}}\right) \\
& V_{o}=\frac{1}{4} \frac{\Delta R}{R} V_{\text {in }}
\end{aligned}
$$

\section{RESULTS AND DISCUSSION}

In this research, there are several stages of the activities applied.

\section{A. Application of Strain Gage Sensor and Cantilever Rod as a Mass Sensor System}

In this study, the strain gage sensor is glued to cantilevered rods made of brass material by using epoxy glue which has elastic properties. This cantilever rod is used because it can change shape due to the load on one end of the cantilevered rod. The loading of the cantilevered rod causes the strain gage to undergo a change in shape, which is followed by a change in the cantilever surface deflection. The gluing result between the strain gage on the cantilever surface is shown in Fig. 7(a).

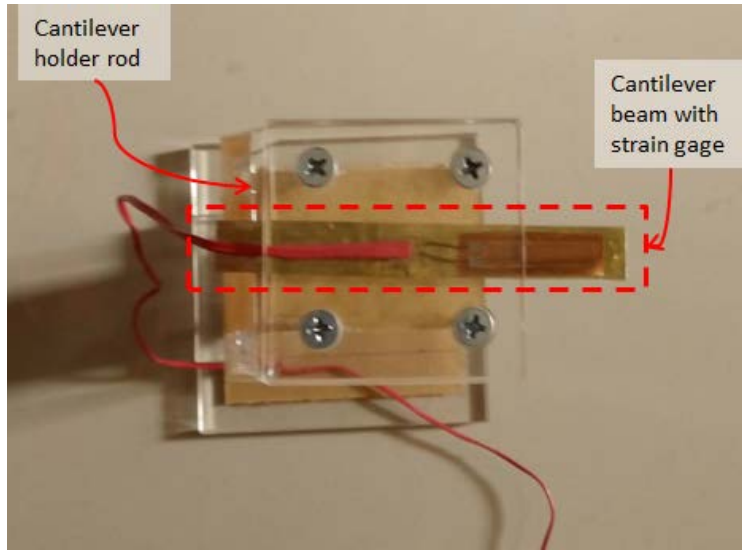

(a)

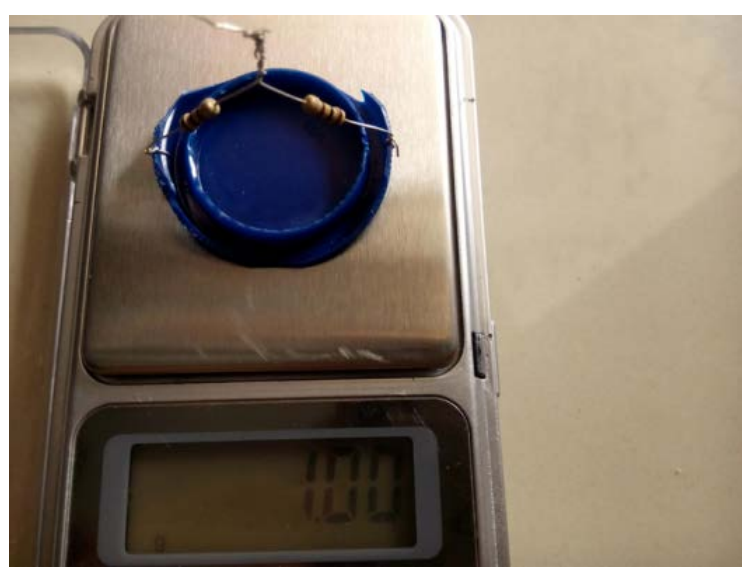

(b)

Fig. 7 Cantilever system, (a) cantilevered rod installation on the frame, (b) hanging plate calibration, weighing 1.00 gram.
To make the integrated cantilevered rods and strain gage sensors function as a mass measuring instrument or mass balance, one of the edges of the cantilevered rod should be statically attached to the frame and at the other end a bowl/ plate is hung for a weight-bearing chamber for stacking on the stem cantilever, as shown in Fig. 7(b). The hanging bowl/plate is made of plastic material and has also been calibrated using digital pocket mass scale.

\section{B. Manufacture of Regulated Power Supply and Differential Amplifier Circuit}

The power supply is required to provide a voltage supply in the Wheatstone bridge circuit of +2 volts, a two-level operational amplifier requiring a voltage of \pm 12 volts, and an 8-bit microcontroller ATmega328P integrated in Arduino module requiring a +5 volt supply voltage. The power supply circuit is shown in Fig. 8. The circuit requires a supply voltage of \pm 18 volts from the CT (center tap) transformer that has been rectified through the bridge rectifier circuit.

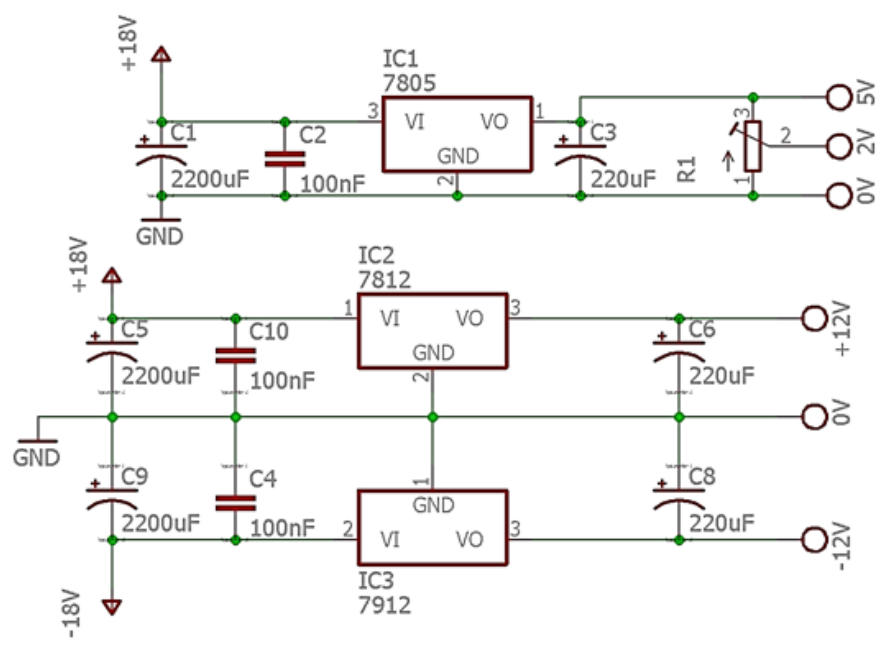

Fig. 8 Regulated power supply circuit.

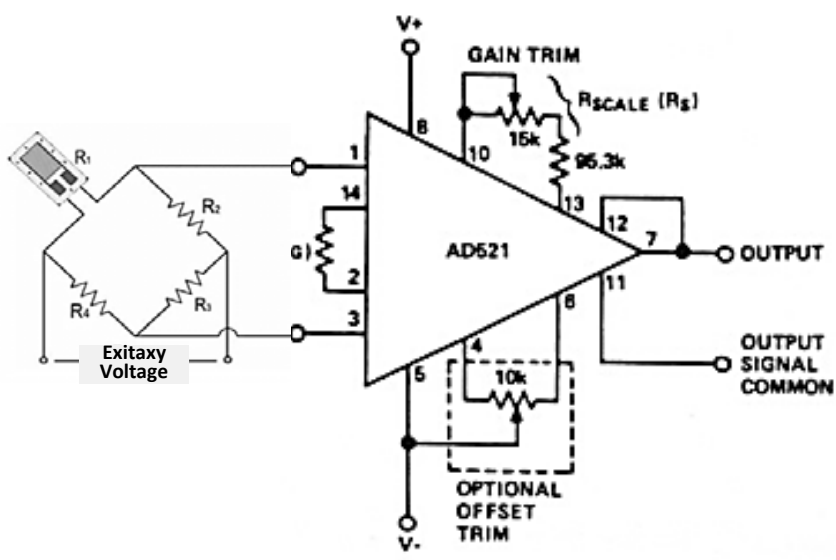

Fig. 9 Differential amplifier circuit connected with Wheatstone bridge.

The +12 volts output voltage is generated from the 7812 regulator IC, the voltage of -12 volts comes from the regulator IC 7912, and the +5 volts voltage comes from the 7805 regulator IC. Meanwhile, the +2 volts voltage is used to 
supply the Wheatstone bridge circuit derived from the voltage divider circuit from variable resistor or potentiometer.

Differential amplifier circuit using IC AD521 with pin 8 given +12 volts voltage supply and pin 5 given -12 volts is shown in Fig. 9.

\section{Calibration}

The electronic balance system is given a mass load of 0.07 grams, measured using pocket mass scale, as shown in Fig. 10. The addition of mass is carried out every 0.07 grams gradually and the deflection changes on the cantilevered rods are observed. The linearity level to the resistance changes of the strain gage sensor is observed as well. The change of resistance $\Delta \mathrm{R}$ is calculated using (4), with already known Vin $=2$ volts, $\mathrm{R}$ strain gage $120 \mathrm{ohm}$, and $\mathrm{V}_{\text {out }}$ value measured using digital multimeter. By testing with a mass of 0.07 grams, the output voltage of the Wheatstone bridge circuit is \pm 0.040 $\mathrm{mV}$ with a resistance change $\Delta \mathrm{R}$ of 0.07 grams. The output voltage relation with the loading mass (black line with black bullet) is shown in Fig. 11.

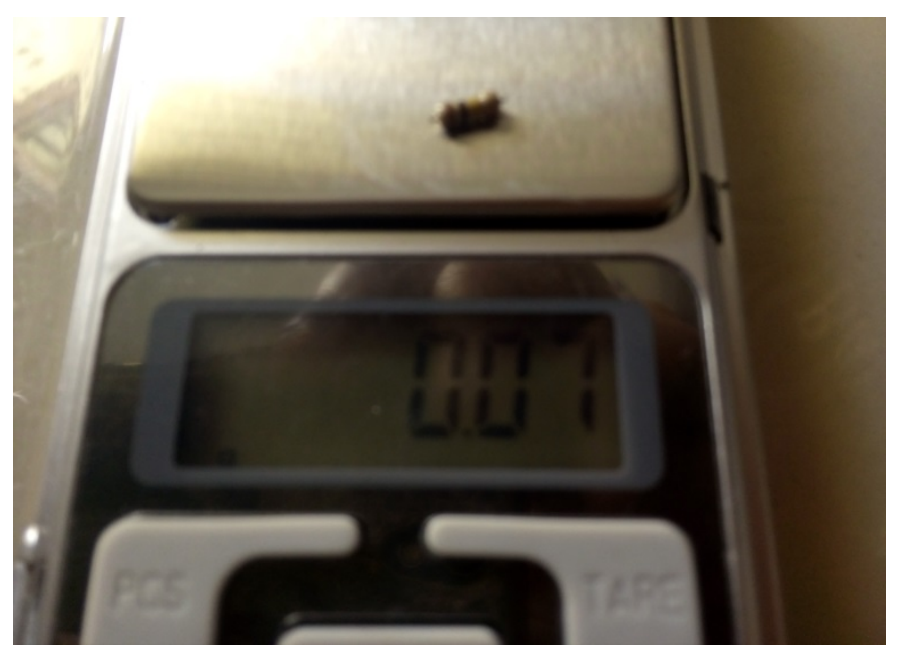

Fig. 10 A mass load of 0.07 grams, measured using pocket mass scale.

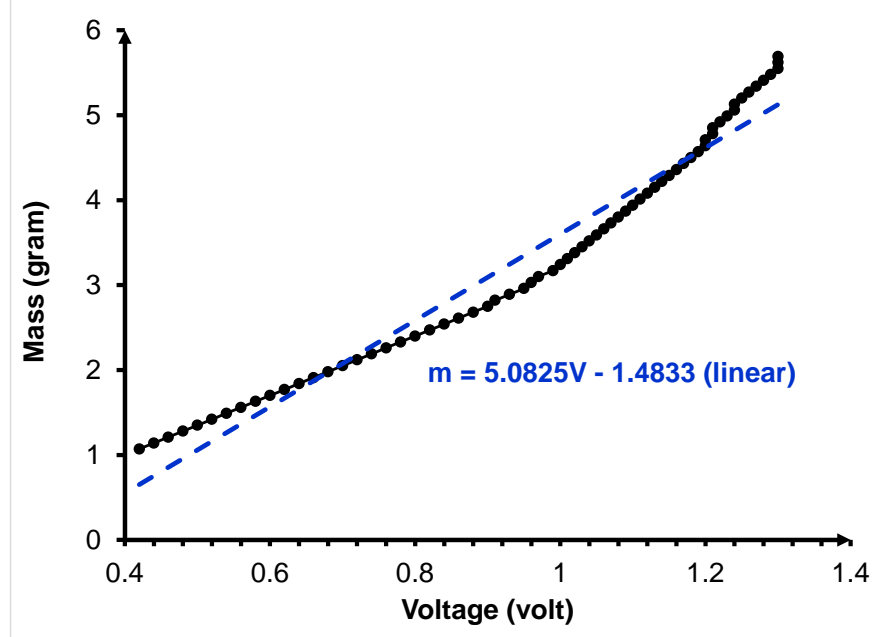

Fig. 11 The voltage relation of the differential amplifier with the 0.07 gram addition mass and linear approximation function.

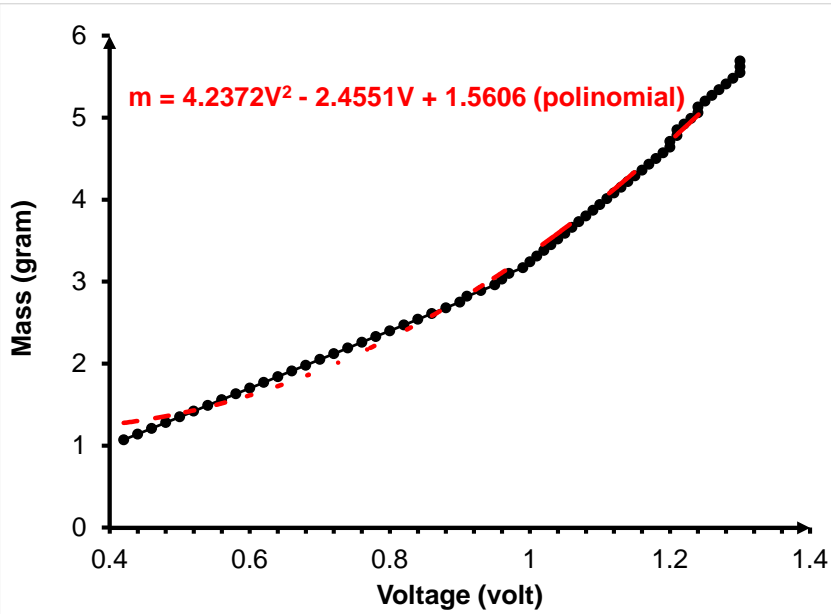

Fig. 12 The voltage relation of the differential amplifier with the 0.07 gram addition mass and the function of the second order polynomial approach.

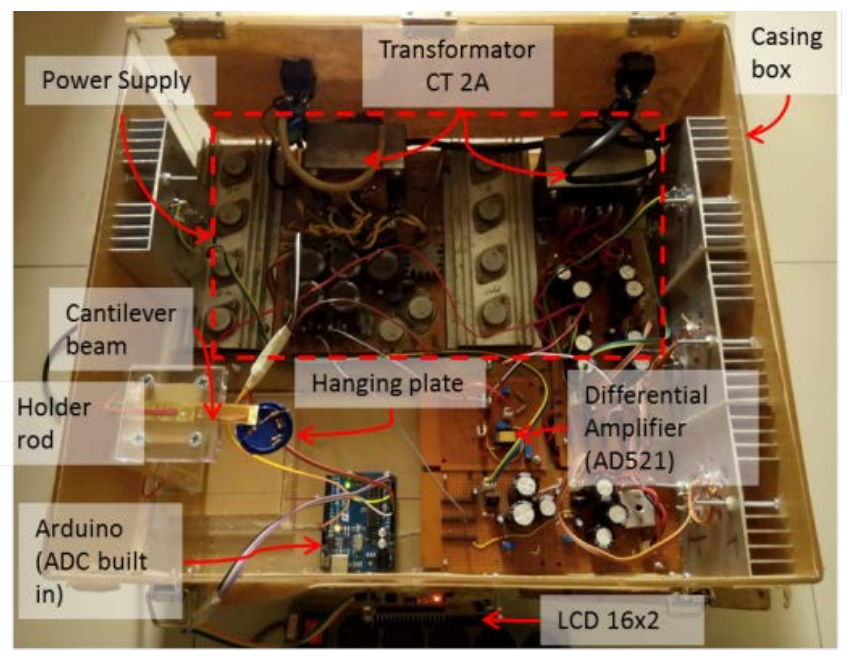

Fig. 13 Electronic mass scale system of gram scale.

Fig. 11 is the measurement result of the addition of mass from 1.07 grams up to 5.69 grams with a multiples of 0.07 grams. Employing curve fitting to be used in ADC conversion equation with a linear approximation, we get the formula $\mathrm{m}=$ $5.0825 \mathrm{~V}-1.4833$, with $\mathrm{m}$ in grams and $\mathrm{V}$ in volt. However, the error rate is quite large, greater than $23 \%$ approximated by linear function approach (blue dash line).

Thus, it is necessary to use polynomial function approach (red line) shown in Fig. 12 and the function $\mathrm{m}=4.2372 \mathrm{~V}^{2}$. $2.4551 \mathrm{~V}+1.5606$ is obtained, with $\mathrm{m}$ in grams and $\mathrm{V}$ in volt. Using this approach, the error rate obtained is relatively small, an average of 0.07 grams. This function is incorporated into the 8-bit ATmega328P in Arduino module. Fig. 12 shows that voltage curve below 0.8 volts on load-mass line fitting and polynomial curve are not overlapped, while above 0.8 volts the curves are overlapped, which means the differences between loading mass value and calculation result are very small.

The entire electronic mass balance system in the gram scale is shown in Fig. 13 which is designed using an acrylic frame 
equipped with a 16x2 matrix LCD display viewer to display the measured mass values.

In digital domain calibration, analog signal voltages are converted into digital signals using 10-bit ADC in the ATmega328P microcontroller. The conversion from analog to digital uses a successive approximation that is expressed in least significant bit (LSB), with the calculation using (5),

$$
\left[1 L S B=\frac{V_{\text {Max }}-V_{\text {Min }}}{2^{n-1}}=\frac{5-0}{2^{10-1}} \approx 4,89 \mathrm{mV}\right]
$$

with,

$$
\begin{aligned}
& \mathrm{V}_{\text {Max }}=\text { maximum input voltage (5 volts), } \\
& \mathrm{V}_{\text {Min }}=\text { minimum input voltage ( } 0 \text { volts), } \\
& \mathrm{n}=\text { bit resolution (10-bit). }
\end{aligned}
$$

Voltage with a value of $5 \mathrm{mV}$ is a voltage after the analog to digital conversion with an accuracy of $\pm 5 \mathrm{mV}$. In this study, the load mass is increased at a multiples of 0.07 grams, ranges from 1 gram to 5.55 grams, and the output voltage on digital conversion shows a minimum voltage figure of 0.42 volts and a maximum voltage of 1.30 volts. If the output voltage of the differential amplifier is 1.30 volts and the voltage value is substituted in the characteristic equation, $\mathrm{m}=4.2372 \mathrm{~V} 2$ $2.4551 \mathrm{~V}+1.5606$, the resulting mass value displayed on the LCD is 5.53 grams. The difference between load mass value (5.55 grams) and calculation result (5.53 grams) is 0.02 grams.

\section{CONCLUSION}

From the result of the research, it can be concluded that the electronic mass balance system can be made using strain gage sensor Uniaxial KFG 120 ohm with AD521 signal amplifier IC, which obtains measurement sensitivity value of 0.07 grams. The graph pattern of electronic mass balance characteristics is approximated by a second order polynomial function, i.e. $\mathrm{m}=4.2372 \mathrm{~V} 2-2.4551 \mathrm{~V}+1.5606$ with $\mathrm{m}$ in gram and $\mathrm{V}$ in volt.

\section{ACKNOWLEDGEMENTS}

The strain gage sensor research is supported by the Instrumentation Physics Laboratory, Faculty of Mathematics and Natural Sciences, Sepuluh Nopember Institute of Technology Surabaya (ITS) Indonesia.

\section{REFERENCES}

[1] Joint Committee for Guides in Metrology, "International vocabulary of basic and general terms in metrology (VIM),” Int. Organ., vol. 2004, no. Dguide 99999, pp. 9-14, 2004.

[2] J. M. Bland dan D. G. Altman, "Comparing methods of measurement: why plotting difference against standard method is misleading," Lancet, vol. 346, no. 8982, pp. 1085-1087, 1995.

[3] H. Syahwanti, A. Nelvi, dan M. S. Hendro, "Rancang Bangun Data Logger Massa Menggunakan Load Cell,” Prosiding SKF 2015, 2015, pp. 211-215.

[4] C. T. University, "5.2 Determination of Modulus of Elasticity." [Online].

Available: https://tpm.fsv.cvut.cz/student/documents/files/BUM1/Chapter15.pdf. [Accessed: 24-Mei-2017].

[5] C. Papavassiliou, "Instrumentation," 2010. [Online]. Available: http://cas.ee.ic.ac.uk/people/dario/files/E302/1Sensorsslides.pdf. [Accessed: 24-Mei-2017].

[6] T. Instruments, "Precision Analog Applications Seminar Bridge Measurement Systems Introduction to Bridge Sensors Circuits for Bridge Sensors A real design: the ADS1232REF The ADS1232REF Firmware." [Online]. Available: www.ti.com/lit/ml/slyp163/slyp163.pdf.

[7] Husnawati, R. Pasarella, Sutarno, dan Rendyansyah, "Perancangan dan Simulasi Energi Meter Digital Satu Phasa Menggunakan Sensor Arus ACS712,” JNTETI, vol. 2, no. 4, pp. 307-315, 2013.

[8] P. D. C. Company, "Alloy Properties." [Online]. Available: http://diecasting.com/resource-center/design-ideas/alloyproperties.php\#properties01. [Accessed: 25-Mei-2017].

[9] Omega Engineering, "New Horizons ${ }^{\circledR}$ in Strain Gages : OME ion BASICS.” [Online]. Available: www.omega.com/literature/omegadyne/omegadyneNH_sg.pdf. [Accessed: 01-Mei-2017].

[10] A. Device, "Integrated Circuit Precision Instrument Amplifier AD521." [Online]. Available: http://www.analog.com/media/en/technicaldocumentation/data-sheets/AD521.pdf. [Accessed: 01-Jan-2017].

[11] R. F. Coughlin dan F. F. Driscoll, Operational Amplifiers and Linear Integrated Circuits, 2nd ed. New Jersey: Prentise Hall, 1982. 